Diana Maksimiuk

\title{
Działalność posłów sejmiku proszowickiego na sejmie ekstraordynaryjnym z 1637 r.
}

\begin{abstract}
Summary
Extraordinary proceedings of Sejm in 1637 were the third such event during the reign of Władysław IV Waza. The King's decision to convene the parliament was criticized by noblemen, but despite the opposition the session was opened on June $3^{\text {rd }} 1637$. Local parliament (sejmik) of Cracow Voievodship was one of the most important in Poland. The MPs elected by this sejmik supported the King's decision. Sejmik also instructed the MPs to support the King in his efforts to prepare the state to Turkish invasion and to get parliamentary consent on new taxes. The MPs were also instructed to support the efforts to establish special Treasury Tribunal in Radom to control the collection of taxes. During the sessions of Sejm in 1637 the MPs from Cracow Voievodship followed the instructions and supported the King. The decisions of this Sejm can be treated as King's success.
\end{abstract}

Parlamentaryzm doby Wazów jako przedmiot badań cieszył się i wiąż chyba cieszy się zainteresowaniem wśród historyków. Choć powstała już znaczna liczba znakomitych pozycji traktujących o parlamentaryzmie lat 1587-1668, to najmniej zbadane zostały rządy Władysława IV Wazy ${ }^{1}$. Wystarczy choćby spojrzeć na monografie sejmów „władysławowskich”. W porównaniu z okresem wcześniejszym (panowanie Zygmunta III Wazy) i późniejszym (panowanie Jana Kazimierza) historycy mają szerokie pole do badań. Spośród bowiem 15 sejmów, które odbyły się pod rządami drugiego na polskim tronie Wazy, tylko sejmy lat

${ }^{1}$ M.in. J. Dzięgielewski, Izba poselska w systemie władzy w czasach Władysława IV, Warszawa 1992; S. Hołdys, Praktyka parlamentarna za panowania Władysława IV, Wrocław 1991. 
1633, 1637 (zwyczajny), 1639 i 1646 doczekały się swoich opracowań2. Lukę tę ostatnio częściowo wypełniła ważna pozycja Przemysława Paradowskiego, traktująca o sejmach ekstraordynaryjnych za panowania Władysława IV, w której autor skoncentrował się na omówieniu zagadnień związanych z procedurą i techniką obrad tego typu zgromadzeńn

Stąd też podjęłam próbę przedstawienia dotychczas całościowo nie omówionego sejmu nadzwyczajnego z $1637 \mathrm{r}$. Ze względu na zakres pracy będzie to jednak spojrzenie na ów sejm z perspektywy jednego tylko sejmiku koronnego, a mianowicie sejmiku województwa krakowskiego, który zbierał się w Proszowicach. Poniższa analiza dotyczy stosunku szlachty krakowskiej do problematyki leżącej u podłoża tego sejmu, jak również działalności parlamentarnej jej reprezentantów podczas obrad w izbie poselskiej.

Dla zrozumienia królewskiej decyzji o zwołaniu w 1637 r. nadzwyczajnego sejmu należałoby się cofnąć do roku 1635, kiedy Władysław IV, podpisując ze Szwecją traktat w Sztumskiej Wsi, zamknął sobie drogę do dziedzicznego tronu szwedzkiego. Zdają się to potwierdzać słowa władcy, w których mówił: „Na lata swoje patrząc, tantundem mi jest zawierać pokój do lat 30 jako i do 60 "4. Przewidując już chyba wtedy, że pozostanie mu zadowolić się tylko koroną polską, zaczął zastanawiać się nad możliwościami wzmocnienia władzy królewskiej oraz zapewnienia sobie mocniejszej pozycji wobec szlachty i magnaterii. Zamierzał to uczynić, uzyskując „wdzięczność” dla siebie i swoich braci za trudy poniesione $\mathrm{w}$ pierwszych latach panowania, a szczególnie za wyrażenie zgody na długoletni rozejm ze Szwecją bez jakiejkolwiek satysfakcji dla swojej rodziny. Pierwsze kroki ku temu poczynił już w 1635 r., by oficjalnie z tymi postulatami wystąpić na styczniowym sejmie 1637 r., kiedy to wysunął roszczenia, domagając się spłacenia swych długów i przyznania mu prawem lenna 8 starostw w Koronie i tyluż na Litwie. Ponadto w parze z pomysłami wzmocnienia pozycji władcy szła nieuchronnie sprawa zwiększenia zasobów skarbu królewskiego, zapewnienia mu stałego poważniejszego dochodu, dzięki czemu można by myśleć o zwiększeniu powagi monarszej. Mając na względzie rozrzutność Władysława IV i liczne wydatki związane z przyszłym weselem oraz z podniesieniem liczebności wojska o 500 nowo zaciągniętych żołnierzy, nie pozostawało nic innego jakzwrócićsiędokies szlacheckich. Takteżwładca uczynił,

${ }^{2}$ Z. Szczerbik, Sejm koronacyjny Władysława IV w 1633 r., Kluczbork - Praszka 2001; R. Kołodziej, Pierwszy sejm z 1637 roku, Toruń 2004; Z. Trawicka, Sejm z roku 1639, „Studia Historyczne” (dalej: SH) 1972, t. 15, z. 4; K. Szajnocha, Dwa lata dziejów naszych 1646-1648, [w:] idem, Dzieła, t. 8-10, 1877-1878.

${ }^{3}$ P. Paradowski, W obliczu „nagłych potrzeb” Rzeczypospolitej. Sejmy ekstraordynaryjne za panowania Władystawa IV Wazy, Toruń 2005.

${ }^{4}$ Cyt. za: W. Czapliński, Władysław IV i jego czasy, Warszawa 1976, s. 224. 
zwołując w 1636 r. sejmiki, do których zwracał się w instrukcjach o skuteczną obronę kraju przed niebezpieczeństwami grożącymi ze strony Moskwy, Krymu i Turcji. Na pierwszym miejscu pisał więc o potrzebie uchwalenia podatków na wojsko i flotę. Przebieg sejmików w tej materii nie zapowiadał niepomyślnego dla króla końca pierwszego sejmu 1637 r. ${ }^{5} \mathrm{~W}$ sprawie z kolei „Wdzięczności” dla domu wazowskiego mógł się spodziewać Władysław IV niepowodzenia w obliczu takich dochodzących ze strony szlachty głosów - „aby dysmembracyjej, alijenacyjej feudami i lennami i żadnym inszym sposobem nie było, bo wielkie stąd były mieszaniny w R. P., kiedy była in partes za przodków naszych poszła i siła prowincyjej tym sposobem odpadła, dlatego słuszną wymówkę od nas królewicz JM. ma przyjąć" ${ }^{6}$. Mimo to nie spodziewał się król, iż rozpoczynający się 20 stycznia 1637 r. sejm będzie pierwszym bezowocnym zgromadzeniem za jego panowania ${ }^{7}$.

Tak więc rozejście się zwyczajnego sejmu bez podjęcia uchwał stało się przyczyną zwołania kolejnego. Decyzja ta zapadła już 4 marca na tajnej radzie z częścią senatorów oraz sporą liczbą posłów koronnych i częścią litewskich. Wówczas to Władysław IV miał prosić posłów, aby na sejmikach relacyjnych uświadomili szlachcie trudną sytuację w kraju i konieczność zwołania nowego sejmu. Sam zaś zobowiązał się dołożyć wszelkich starań, aby zapewnić bezpieczeństwo granicom $\mathrm{kraju}^{8}$. Zwołanie przyszłego sejmu na 6 czerwca 1637 r. ustalono na kolejnej tajnej radzie 6 marca, na której ponadto uchwalono zapewnienie zapłaty żołnierzom, a nawet pozwolono zaciągnąć ich więcej. Jak donosił Albrycht Stanisław Radziwiłł, „te dwie sprawy uraziły wolność szlachecką, bowiem słyszałem z ust skarżących się, że nie godzi się to królowi do woli samemu z senatem załatwiac'" . Pierwszy raz się zdarzyło, by w ten sposób Władysław IV zwołał sejm ekstraordynaryjny. Dotychczasowe nadzwyczajne zgromadzenia za jego panowania - zarówno sejm z $1634^{10}$ r., jak i sejm listopadowy roku $1635^{11}$ - odbyły się zgodnie z prawem „za pozwoleniem konstytucyją sejmu blisko przeszłego wyrażonym". Sejm ekstraordynaryjny bowiem mógł być

${ }^{5}$ J. Dzięgielewski, O tolerancję dla zdominowanych. Polityka wyznaniowa Rzeczypospolitej w latach panowania Władysława IV, Warszawa 1986, s. 102.

${ }^{6}$ Instrukcja proszowicka z 9 grudnia 1636 roku, [w:] Akta sejmikowe województwa krakowskiego (dalej: ASWK), wyd. A. Przyboś, t. 2, cz. 1, Warszawa 1953, s. 213.

${ }^{7}$ O przyczynach rozejścia się tego sejmu zob. R. Kołodziej, op. cit., s. 230-235.

${ }^{8}$ Ibidem, s. 228-229.

${ }^{9}$ A. S. Radziwiłł, Pamiętnik o dziejach w Polsce, wyd. A. Przyboś i R. Żeleński, t. 2, Warszawa 1980, s. 26.

${ }^{10}$ Sejm dwuniedzielny z 19 lipca 1634 roku; Seym dwuniedzielny, [w:] VL, t. 3, s. 373; ASWK, t. 2, cz. 1, s. 180-181.

${ }^{11}$ Sejm dwuniedzielny z 22 listopada 1635 roku; Seym dwuniedzielny, [w:] VL, t. 3, s. 413; ASWK, t. 2, cz. 1, s. 195. 
zwołany jedynie w wypadku, gdy poprzedzający go sejm wyraził na to zgodę i uchwalił odpowiednią konstytucję.

Zgromadzenie tego typu było zwoływane więc przez inny organ niż króla, czyli poprzedni sejm zwyczajny, który to przesądzał merytorycznie o sejmie nadzwyczajnym. Swoboda władcy w zakresie podejmowania decyzji o składaniu sejmówekstraordynaryjnych,gwarantowanawartykułachhenrykowskich,została ograniczona w ten sposób, że bez konstytucji sejmowej nie mógł on zwoływać takich sejmów. Uchwalenie natomiast takiej konstytucji dawało mu swobodę dalszego działania. Nie przewidziano jednak w tej procedurze postępowania na wypadek zerwania sejmu i konieczności złożenia kolejnego w obliczu „pilnej a gwałtownej potrzeby Rzeczypospolitej” ${ }^{12}$. Stąd decyzja Władysława IV w zaistniałej w 1637 r. sytuacji różnie została oceniona przez ówczesną szlachtę. Nie wnikając $\mathrm{w}$ kwestię prawomocności zwołania czerwcowego sejmu, warto zwrócić uwagę na spostrzeżenia Przemysława Paradowskiego ${ }^{13}$. Uważa on, że Władysław IV, podejmując decyzję o krótkim sejmie w porozumieniu $\mathrm{z}$ senatorami, uczynił to w zgodzie z artykułami henrykowskimi. A, że siłą rzeczy sejmu tego nie mogła poprzedzać konstytucja sejmu przeszłego, to nie było podstawy zwyczajowej do jego złożenia. W rezultacie sejm ten został zwołany wbrew ukształtowanemu zwyczajowi, ale zgodnie z prawem „kardynalnym” Rzeczypospolitej.

Szlachta krakowska, zgodnie z uniwersałem królewskim zwołującym sejmik na 11 maja, zebrała się tego dnia w Proszowicach. Pod przewodnictwem marszałka sejmikowego, którym obrano miecznika koronnego, Jana Zebrzydowskiego, rozpoczęła obrady nad problemami wysuniętymi przez króla $\mathrm{w}$ instrukcji. W pierwszej kolejności z ust legata królewskiego usłyszała, iż władca nie chcąc „deesse JKM. sławie i bezpieczeństwu państw swoich”, a „upatrując wielkość niebezpieczeństw” składa sejm dwuniedzielny, ponieważ: „Jeśli który czas szczęśliwego zawarcia sejmu i obmyślawania na nim (...) bezpieczeństwa Rzplitej potrzebował, ten teraźniejszy był taki, że i do wewnętrznego uspokojenia, i do (...) niebezpieczeństwom postronnym zabieżenia, i do nieśmiertelnej narodu naszego sławy wielką podawał okazyją. A to za wyrokiem skrytym Bożym, za pomieszaniem zdrowych rad i nieszczęściem tej Ojczyznej (...), nie przyszło do konkluzyjej sejmowej” ${ }^{14}$. Powołał się więc Władysław IV, uzasadniając zwołanie sejmu ekstraordynaryjnego, właśnie na fakt rozejścia się bez uchwał sejmu

${ }^{12}$ P. Paradowski, „Dla gwałtownych także spraw y potrzeb Rzeczypospolitej”. Z procedury zwoływania sejmów ekstraordynaryjnych za Władysława IV Wazy, [w:] Z badań nad Rzeczypospolita $w$ czasach nowożytnych, pod red. K. Matwijowskiego, „Prace Historyczne” (dalej: PH) 2001, t. 31, s. 16-18.

${ }^{13}$ Zob. idem, Konflikt wokół prawomocności sejmu nadzwyczajnego z 1637 roku, [w:] Studia $z$ dziejów XVII i XVIII wieku, pod red. K. Matwijowskiego i B. Roka, PH 2003, t. 33, passim.

${ }^{14}$ Instrukcja królewska z kwietnia 1637 roku, [w:] Akta do dziejów Polski na Pomorzu 1632-1648 (dalej: APM), wyd. W. Czapliński, t. 7, cz. 2a, Gdańsk 1959, s. 1-2. 
i wynikające z tego niebezpieczeństwa, którym koniecznie należało stawić czoła, tym bardziej, iż „pory wojenne nastąpią”. Stąd w dalszej części legacji znalazł się szeroki opis niebezpieczeństw zewnętrznych zbliżających się ze strony Tatarów i Turków. Król przedstawił czarną wizję przyszłości, pisząc że „chan, nie mając w Wołoszech żadnego wstrętu i oglądając się za Dunajem na potęgę turecką niechybnie z Turki do kompozycyjnej przyjść musi (...) i koszty podjęte dla przychęcenia i ukontentowania wojska swego i za powodem tureckim szkody z państw koronnych nagradzać i wetować prędko zechce"15. Na ile jednak to uwypuklenie zagrożeń było rzeczywiste?

Można spotkać się $\mathrm{z}$ opinią, że i tym razem posłużono się „pogańskim straszakiem", by zrealizować koncepcję polityki dworu ${ }^{16}$. Miałbowiem Władysław IV mieć nadzieję, że stworzy sobie na południu dziedziczne państwo z posiadłości tureckich. Myśl ta, którą władca kilkakrotnie już starał się urzeczywistnić, i której ostatnia faza (1645-1647) została wszechstronnie wyświetlona przez Wiktora Czermaka ${ }^{17}$, wypłynęła, z pełną świadomością, w umyśle króla i szukała już realizacji od roku 1636. Wprawdzie zagrożenie Polski ze strony Turcji w 1634 r. było najlepszą okazją, by to uczynić, jednak wówczas monarcha nie podjął żadnych działań. Zawarcie pokoju z Turcją dawało mu z kolei spokojne wtedy skierowanie wysiłków na północ, w celu odzyskania swego szwedzkiego dziedzictwa. Straciwszy na to nadzieję, zwrócić miał teraz uwagę na południe i tu szukać realizacji swych planów ${ }^{18}$.

Już wiosną 1636 r. rozchodziły się po Rzeczypospolitej wiadomości o niebezpieczeństwie tureckim. Wówczas poseł księcia siedmiogrodzkiego miał donosić, że brat Bethlena Gábora, István Bethlen, ubiega się o Siedmiogród, i że przyjął w tym celu islam, a nawet otrzymał konkretną obietnicę sułtana ${ }^{19}$. Dalsze wiadomości przynosiły szczegóły, tj. zbieranie się wojsk sułtana i jego marsz na Adrianopol, nieprzychylne przyjęcie posła polskiego Jerzego Kruszyńskiego w Konstantynopolu, wrogie stanowisko wobec Rzeczypospolitej wojewody wołoskiego, usadowienie się na stepach buczackich Tatarów Kantymira, którzy zbuntowawszy się przeciw chanowi krymskiemu przenieśli swe siedziby pod Białogród, Tehin, Kilię aż pod Multany ${ }^{20}$. Stąd w legacji król zapytywał szlachtę: „Cóż w tej bliskości za bezpieczeństwo obiecować sobie WM. możecie? Jeno na przeszłe patrząc calamitates, któreście od odległych Tatar ponosili, od tak

${ }^{15}$ Ibidem, s. 3.

${ }^{16}$ P. Paradowski, $W$ obliczu, op. cit., s. 61.

${ }^{17}$ W. Czermak, Plany wojny tureckiej Władysława IV, Kraków 1895, passim.

${ }^{18}$ W. Czapliński, Władysław IV, op. cit., s. 357.

${ }^{19}$ W. Godziszewski, Polska a Moskwa za Władysława IV, Kraków 1939, s. 48.

${ }^{20}$ Zob. Korespondencja Stanisława Koniecpolskiego hetmana wielkiego koronnego 1632-1646, oprac. A. Biedrzycka, Kraków 2005. 
bliskich, którzy na samych granicach państw Rzplitej leżą, spodziewać się przychodzi" ${ }^{21}$. Pierwsza podjęta przez Władysława IV na sejmie zwyczajnym 1637 roku próba nakłonienia szlachty do wojny zaczepnej przeciw Turcji zakończyła się fiaskiem. Choć okoliczności sprzyjały - Wielka Porta prowadziła wojnę z Persją, istniały spory w łonie tatarszczyzny, które otwierały widoki wykorzystania Tatarów do walki przeciw sułtanowi ${ }^{22}$, sam hetman wielki koronny Stanisław Koniecpolski wyraziłgotowość do walki zodwiecznym wrogiem chrześcijaństwa ${ }^{23}$ - to szlachta ze znanym w owym czasie pacyfizmem ${ }^{24}$ nie wyrażała zgody na bellum offensivum przeciwko Turkom ${ }^{25}$. W tych okolicznościach król, aby pozyskać „serca i umysły” sejmikujących i aby na zbliżającym się sejmie ekstraordynaryjnym nie spotkać się z porażką, musiał po zerwanym sejmie 1637 roku użyć przekonujących argumentów.

W tym celu posłużyłsię władca propagandą. Po Rzeczypospolitej krążyło wiele pism ulotnych donoszących o niebezpieczeństwie tureckim. Potwierdzeniem tych wiadomości miały być doniesienia Stanisława Koniecpolskiego o sytuacji na pograniczu ${ }^{26}$, czy listy docierające na dwór królewski z Moskwy, donoszące „że się Turczyn wielką potęgą gotuje na wojnę"27. Wiele sejmików, nie ufając słowom monarchy, uzależniało swoje decyzje od informacji z terenów rzekomo zagrożonych najazdem. Ta nieufność do króla, jako instytucji, była cechą charakterystyczną ówczesnej kultury szlacheckiej ${ }^{28}$. Stąd chcąc zniwelować tę podejrzliwość, kancelaria królewska odwoływała się nie tylko do zdrowego rozsądku, ale także do emocji i uczuć sejmikującej szlachty. Tym razem również autorzy legacji postanowili odnieść się do wartości szlacheckich - „ma JKM.

${ }^{21}$ Instrukcja królewska z kwietnia 1637 roku, [w:] APM, s. 2.

${ }^{22} \mathrm{Na}$ wiosnę $1635 \mathrm{r}$. nowym władcą Krymu został Inajet Gorej, który okazał się niezbyt wygodnym wasalem sułtana. Rozpoczął bowiem staranie o zjednoczenie tatarszczyzny. Aby tego dokonać, musiał rozprawić się z ordą budziacką Kantymira, który z kolei cieszył się poparciem sułtana. Na pokonaniu niewygodnego sąsiada, zamieszkującego stepy budzicie, zależało Rzeczypospolitej od dawna, jednak wojna wśród Tatarów niosła ze sobą niebezpieczeństwo dla ziem pogranicznych kraju. R. Kołodziej, op. cit., s. 28.

${ }^{23}$ „Pan Bóg sam podaje nam okazyje, abyśmy kiedykolwiek uwolnili się z niewczasów i sąsiedztwa tak bliskiego z tym pogaństwem". List Stanisława Koniecpolskiego do Władysława IV, Kamionka 11 III 1637. Korespondencja, op. cit., s. 352.

${ }^{24}$ J. Dzięgielewski, Pokój $i$ wojna w opinii szlachty Rzeczypospolitej czasów Władysława IV, [w:] Kultura, polityka, dyplomacja. Studia ofiarowane Profesorowi Jaremie Maciszewskiemu w 60. rocznice Jego urodzin, Warszawa 1990, s. 137.

${ }^{25}$ Cyt. za: W. Godziszewski, Polska a Moskwa, op. cit., s. 57.

${ }^{26}$ Zob. List Stanisława Koniecpolskiego do Piotra Gembickiego, Sokal 1 VI 1637; List Tegoż do Władysława IV, Sokal 1 VI 1637; List Tegoż do Tomasza Zamoyskiego, Kryłów 2 VI 1637. Korespondencja, op. cit., s. 376-377.

${ }^{27}$ Cyt. za: W. Godziszewski, Polska a Moskwa, op. cit., s. 60.

${ }^{28}$ E. Opaliński, Kultura polityczna szlachty polskiej w latach 1587-1652. System parlamentarny a społeczeństwo obywatelskie, Warszawa 1995, s. 56. 
zupełną w miłosierdziu Bożym nadzieję (...), że WM. w tym nie ustąpicie przodkom swoim, ale za wiarę, za całość swoję, za to, co macie najmilszego, i to, co każdy status requirit, za dostojeństwo pańskie, nieśmiertelność narodu swojego imienia tak się stawicie, jakbyście i przed Panem Bogiem i potomnością całą sławę ozdoby przy wolnościach od przodków swoich wzięte zachowali”29. Instrukcja królewska za pomocą takich zabiegów potrafiła przybrać kształt dobrej literatury politycznej.

Problemami związanymi bezpośrednio z zagrożeniem „pogańskim” były: spłata zaległego żołdu, utrzymanie wojska na Ukrainie oraz nowe zaciągi wojskowe. Narastający dług wobec wojska i brak w tej kwestii decyzji sejmu zwyczajnego sprawiły, że stała się ona kluczowym punktem legacji ${ }^{30}$. Przede wszystkim sprawne wojsko było warunkiem niezbędnym bezpieczeństwa Rzeczypospolitej, a ponadto nieopłaceni żołnierze sami wybierali sobie żołd, wyrządzając ogromne szkody w miejscach swego pobytu. W związku z tym Władysław IV przypominał w legacji o konieczności opłacenia wojska, które po zerwanym sejmie w marcu $1637 \mathrm{r}$. postanowił zatrzymać w dalszej służbie, „by opatrzyć bezpieczeństwo Rzplitej”31. To pozostawienie wojska bez zgody sejmu było według obowiązującego w Rzeczypospolitej prawa nielegalne, stąd $\mathrm{w}$ instrukcji królewskiej podjęto także próbę usprawiedliwienia tej decyzji. Legat argumentował, że „nie było to w mocy JKM-ci voto tylko zahamować zamysły pogańskie”, a wiedząc dobrze o tych zamysłach „nie mógł JKM inaczej postąpić" ${ }^{2}$. Na tę kwestię nałożyła się jeszcze kolejna - konieczność zapłaty żołdu nowemu zaciągowi, który został uchwalony na radach senatu 4 i 6 marca 1637 r. Trudny problem miał do rozwiązania władca, tym bardziej, że już wcześniej (od 1 marca 1636 r.), powiększając liczebność wojska na Ukrainie, spotkał się z nieprzychylnym przyjęciem tej decyzji przez opinię szlachecką ${ }^{33}$.

Innym problemem, związanym $\mathrm{z}$ obronnością państwa, a podniesionym przez Władysława IV w instrukcji królewskiej, było ostateczne rozwiązanie kwestii fortu na Kudaku. Decyzję o budowie tego zamku na wyspie Dniepru podjęto w 1635 r. uchwałą sejmu zwyczajnego, na co przeznaczono $100000 \mathrm{zł}^{34}$. Kudak spełniać miał głównie funkcję twierdzy kontrolującej komunikację między Ukrainą grodową, a także zapobiegać wyprawom kozackim przeciw Turcji. Budowa fortu rozpoczęta wiosną tego roku po 4 miesiącach została przerwana

${ }^{29}$ Instrukcja królewska z kwietnia1637 roku, [w:] APM, s. 4.

${ }^{30} \mathrm{Ibidem}$, s. 2.

${ }^{31}$ Ibidem.

${ }^{32}$ Ibidem.

${ }^{33}$ A. Filipczak-Kocur, Skarb koronny za Władysława IV, Opole 1991, s. 61.

${ }^{34}$ Pohamowanie inkursyi morskich, od woyska Zaporowskiego, [w:] VL, t. 3, s. 403-404; W. Serczyk, Na dalekiej Ukrainie, dzieje Kozaczyzny do 1648 roku, Kraków 1984, s. 327. 
jeszcze we wrześniu najazdem hordy Kozaków nierejestrowych na czele z Iwanem Sulimą. Choć Kozakom udało się utrzymać tylko przez kilka dni, to pozostał problem zburzonej twierdzy. Kwestia konieczności naprawy Kudaku pojawiła się już na pierwszym sejmie 1637 r., ale wobec fiaska obrad pozostała nierozstrzygnięta ${ }^{35}$. Stąd powróciła niechybnie $w$ instrukcji przed sejmem czerwcowym, a że fort potrzebny był „dla zahamowania inkursyi kozackich na Czarne Morze (...) przeto król sobie życzył aby gruntownie stanął i żołnierzem a municyją był dobrze opatrzony" ${ }^{36}$. Znamienne przy tym jest pytanie, dlaczego odbudowa twierdzy nie została jeszcze ukończona, skoro już wcześniej (w 1635 roku) pieniądze zostały na ten cel uchwalone.

Przy tej okazji wspomniał król również o konieczności podjęcia decyzji dotyczących hiberny. Podatek ten bardzo dokuczliwy, stosunkowo wysoki i dający okazję do nadużyć, nie mógł być mile widziany. Narzekania szlachty nie były tu z pewnością bezpodstawne, bo żołnierz nie liczył się często z niczyimi łzami i łupił wszystko, co popadło ${ }^{37}$. Życzył więc sobie Władysław IV, „aby dla uciążenia i skwiru ludzkiego hiberny były dla wojska uchwałą sejmu postanowione, żeby tym sposobniej Rzplitej służbę odprawować mogli”38. Mógł się władca liczyć z przychylnym przyjęciem przez szlachtę krakowską tego postulatu, a to z tego prostego powodu, że żołnierz nie mając nic do złupienia w dobrach królewskich, sięgnie w końcu po dobra szlacheckie.

W dalszej części legacji jej autorzy poruszyli nierozstrzygniętą kwestię granicy polsko-moskiewskiej. W myśl traktatu pokojowego z Polanowa z 1634 roku rozgraniczenie między obu państwami miało być zakończone w $1635 \mathrm{r}$., a zostało doprowadzone do skutku jedynie na odcinku toropieckim, gdzie granice nie były zbyt sporne. Większe trudności sprawiał odcinek putywlski, a to ze względu na większą wartość ziem, które stanowiły przedmiot konfliktu oraz silniejsze zagospodarowanie się tu magnatów polskich ${ }^{39}$. Król ociąganie się strony moskiewskiej z zakończeniem prac komisji rozgraniczającej wykorzystał, aby w negatywnym świetle przedstawić Moskwę, która „abo umyślnie sobie z nami szuka do rozerwania przymiernego pokoju okazyjej, abo coś tajemnego i skrytego z cesarzem tureckim, z którym się ustawicznie zseła poselstwy, zamyślawa" ${ }^{40}$. Zdaje się, że i w tym przypadku pogłoska o niebezpieczeństwie

${ }^{35}$ A. Filipczak-Kocur, Skarb, op. cit., s. 49-51; eadem, Skarbowość Rzeczypospolitej 1587-1648. Projekty - ustawy - realizacja, Warszawa 2006, s. 184-185; R. Kołodziej, op. cit., s. 90.

${ }^{36}$ Instrukcja królewska z kwietnia 1637 roku, [w:] APM, s. 3.

${ }^{37}$ M. Talik, Stanowisko sejmików mało- $i$ wielkopolskich wobec spraw podatkowych $w$ pierwszej i na początku drugiej połowy XVII w., „Acta Universitatis Wratislaviensis” (dalej: AUW) 1981, Historia , z. 34 , s. $75-76$.

${ }^{38}$ Instrukcja królewska z kwietnia 1637 roku, [w:] APM, s. 3.

${ }^{39}$ W. Godziszewski, Granica polsko-moskiewska wedle pokoju polanowskiego, Kraków 1934, s. 22-24.

${ }^{40}$ Instrukcja królewska z kwietnia 1637 roku, [w:] APM, s. 3. 
ze strony - tym razem Moskwy - miała być tylko środkiem poruszenia opinii publicznej do skutecznej obrony tego pogranicza. Świadczą o tym fałszywe wieści krążące po Rzeczypospolitej z informacjami o układach i poselstwach między Turcją a Moskwą. Rzekomy poseł moskiewski, który miał prowadzić rokowania nie był wcale posłem, tylko tłumaczem (co miało nawet rozzłościć sułtana), wysłanym z zadaniem wyjaśnienia przyczyn zawarcia pokoju z Rzeczpospolitą ${ }^{41}$. Przyznać jednak należy, iż stosunki polsko-moskiewskie cechowała wzajemna nieufność i podejrzliwość. Wielu doradców króla, w tym będący najbliżej tematu Adam Kisiel, dwukrotny komisarz graniczny, uważało, że chcąc uspokoić granicę wschodnią, należy doprowadzić do skutku rozgraniczenie, by tym samym nie dać sąsiadowi żadnego pretekstu do roszczeń ${ }^{42}$. Sprawa wyglądała więc na poważną. $\mathrm{Na}$ ile zaś poważnie potraktowała ją szlachta krakowska?

W kolejnym punkcie legacji znalazła się propozycja królewska uchwalenia przez sejm konstytucji o powołaniu Trybunału Radomskiego, w celu odzyskania zaległości od retentorów i przekazaniu ich na zapłatę „wojsku borgowemu”"33. Za Władysława IV Trybunał Radomski powoływano już wcześniej trzy razy - w 1633, 1634 i 1635 roku - stąd propozycja królewska w tej materii nie była nowością ${ }^{44}$.

$\mathrm{Na}$ zakończenie $\mathrm{w}$ additamencie legacji znalazła się prośba monarchy, by w związku ze śmiercią księcia pomorskiego Bogusława XIV (zm. 10 marca 1637 roku) z powracających „ad gremium et corpus Regni et Republice jako membra” powiatów lęborskiego i bytomskiego, sum niemałych się rozliczyćc ${ }^{45}$. Powiaty te zostały oddane w zastaw przez Zygmunta Augusta za 100 tys. talarów książętom pomorskim na Słupsku. Stanowiąc lenno polskie po wymarciu tej dynastii, miały powrócić do Rzeczypospolitej ${ }^{46}$. Wobec nie rozliczenia się z pożyczonych kwot od śmierci ostatniego z Jagiellonów pozostawał trudny problem do rozwiązania, tym bardziej, iż na poprzednim sejmie większość województw w tej sprawie wymawiała się od spłaty długów, dowodząc że zaciągnięte one zostały bez zgody Rzeczypospolitej ${ }^{47}$.

Owocem obrad sejmiku było spisanie instrukcji poselskiej, która odzwierciedlała stosunek sejmikującej szlachty do przedstawionej przez dwór problematyki. Zadowolić musiał Władysława IV fakt, że sejmik proszowicki nie zakwestionował prawomocności zwołania sejmu, jak to uczynił choćby sejmik

${ }^{41}$ W. Godziszewski, Polska a Moskwa, op. cit., s. 53.

${ }^{42}$ Ibidem, s. 52.

${ }^{43}$ Wojsko służące na kredyt. Instrukcja królewska z kwietnia 1637 roku, [w:] APM, s. 4.

${ }^{44}$ A. Filipczak-Kocur, Skarbowość, op. cit., s. 39, przyp. 90.

${ }^{45}$ Instrukcja królewska z kwietnia 1637 roku, [w:] APM, s. 5.

${ }^{46}$ R. Kołodziej, op. cit., s. 25.

${ }^{47}$ Szlachta krakowska wówczas uważała, że pożyczone sumy powinni oddać obywatele tychże dwóch powiatów. Ibidem, s. 93. 
średzki, a wręcz przeciwnie - poparł decyzję królewską. Szlachta krakowska już na samym wstępie instrukcji mocno potępiła tych, którzy „przeszły sejm ważeli się rozerwać” i życzyła, aby „J. K. M. z stanami raczeł inire modos, jako by się przez pokaranie tych, (którzy nie mając fundamentu z prawa pospolitego, alie telko idąc za prywatami swemi tego ważeli) na potym takim zabieżało postępkom, za któremi by prędka zguba Ojczyzny nastąpić mogła"48.

Sejmikujący $\mathrm{z}$ całą powagą potraktowali niebezpieczeństwo najazdu ze strony Turcji. Postanowili, by wybrani przez nich posłowie, „znosząc się (...) z stanami wszytkimi na zabieganie temu niebezpieczeństwu i obronę przy ścienie swyj telko stojąc, obmyślili, jak nabarzij to warując, aby w wojnę (...) nie beliśmy zaciągnieni" ${ }^{2}$. Szlachta krakowska w żadnym wypadku, jak widać, nie wyrażała zgody na wojnę ofensywną, a jedynie na obronę pogranicza oraz zwołanie pospolitego ruszenia, ale tylko pod warunkiem, że „pieniężna obrona (...) od Turczyna nie beła sufficiens" ${ }^{\prime 50}$. Jak słusznie spostrzegł Jan Dzięgielewski, poprzez pospolite ruszenie szlachta wyrażała "gotowość do wypełnienia powinności obrony Rzeczypospolitej, uniemożliwiając jednocześnie ewentualne przejście do działań zaczepnych"51. Z kolei kwestia zagrożenia moskiewskiego nie została w ogóle poruszona w instrukcji poselskiej. Sejmikujący nie zaufali więc informacji królewskiej o rzekomych knowaniach tego „dziedzicznego nieprzyjaciela" ${ }^{\prime 2}$.

Do kolejnej sprawy, zapłaty żołdu żołnierzowi suplementowemu, czyli zaciągniętemu bez zgody sejmu, odniesiono się w instrukcji również z niechęcią. Szlachta postawiona przed faktem dokonanym (nowy zaciąg wojska, jak wiemy, postanowiono już na radzie senatu po zerwanym sejmie zwyczajnym 1637 r.) z jednej strony zaakceptowała konieczność zapłaty żołdu temuż wojsku, "nie chcąc w tym razie deesse Ojczyźnie” ${ }^{53}$. Z drugiej strony zastrzegła, aby w przyszłości takie suplementy nie były zaciągane przez króla bezzgody wszystkich stanów. Tak więc w sumie zobowiązano posłów do dołożenia wszelkich starań, by wojsko zostało opłacone. Jednocześnie zastrzegano, że zebranie pieniędzy na ten cel powinno odbyć się bez „uciążenia ubogich”. Dlatego też posłowie krakowscy mieli się „znosić z inszemi województwy”, choćby w sprawie hiberny ${ }^{54}$.

\footnotetext{
${ }^{48}$ Instrukcja proszowicka z 11 maja 1637 roku, [w:] ASWK, t. 2, cz. 1, s. 224.

${ }^{49}$ Ibidem.

${ }^{50}$ Ibidem.

${ }^{51}$ J. Dzięgielewski, Wojna i pokój w opinii szlachty, op. cit., s. 134.

${ }^{52}$ Instrukcja królewska z kwietnia 1637 roku, [w:] APM, s. 3.

${ }^{53}$ Instrukcja proszowicka z 11 maja 1637 roku, [w:] ASWK, t. 2, cz. 1, s. 224.

${ }^{54}$ Ibidem, s. 226.
} 
W dalszej części instrukcji proszowickiej znalazły się propozycje uzyskania sum niezbędnych do utrzymania bezpieczeństwa i funkcjonowania państwa. Szlachta, dowiadując się o braku w skarbcu pieniędzy, nakazywała zwykle na przyszłym sejmie skontrolować prawidłowość przekazywania i wydawania uchwalanych wcześniej podatków. Wiązało się to głównie z rozliczeniem podskarbich, odzyskaniem pieniędzy od retentorów, przeprowadzeniem koekwacji podatkowej i domaganiem się równej partycypacji w wydatkach obywateli wszystkich ziem Rzeczypospolitej ${ }^{55}$. Tak było i tym razem. Sejmikujący domagali się, by „panowie podskarbiowie” rzetelnie wywiązywali się ze swoich obowiązków - „długi odzyskiwali, surowie na tych retentorów i faliatów następując i do egzekucji przywodząc"56. Miało $\mathrm{w}$ tym pomóc, proponowane $\mathrm{w}$ legacji przez króla, uchwalenie Trybunału Radomskiego, czemu szlachta z Proszowic wyrażała $\mathrm{w}$ instrukcji poparcie $\mathrm{e}^{57}$. Ponadto pojawił się postulat, aby „retenta pozostałych podatków” w Wielkim Księstwie Litewskim „nigdzie indzi, telko na obronę R. P. obrócone beły" oraz żądanie przeprowadzenia na sejmie koekwacji ${ }^{58}$.

Przy okazji nakazów kontroli podskarbich sejmik proszowicki wskazywał na wiele nieprawidłowości w wydawaniu zebranych środków. Przy tym nie był skory przebaczać poborcom i szafarzom popełniającym nadużycia finansowe we własnym województwie ${ }^{59}$. Świadczy o tym żądanie, aby poborca nie pobierał dodatkowych opłat przy rozliczaniu osób płacących podatki, co też pragnął, aby „beło lege publica cautum” ${ }^{60}$. Poza tym posłowie krakowscy mieli „efficere”, by inne nadużycia podskarbich, polegające na wybieraniu podatków, których „już czas odbierania wedle prawa ekspirował", zostały ukrócone ${ }^{61}$.

$\mathrm{Na}$ pierwszy plan, jak więc widać, wybija się dążenie szlachty krakowskiej, jako równych i posiadających prawa polityczne obywateli, do kontroli wydatkowania zebranych w skarbie pieniędzy. Postawa taka była czymś zupełnie naturalnym i wcale nie musiała wynikać z powszechnej niechęci szlachty do płacenia podatków.

Spośród pozostałych problemów proponowanych w legacji na sejmiki $\mathrm{w}$ instrukcji poselskiej poruszono jeszcze tylko sprawę przyłączonych do Rzeczypospolitej powiatów lęborskiego i bytowskiego ${ }^{62}$. Inne zaś kwestie nie znalazły odzewu, jak choćby kwestia kozacka. Być może wynikało to

\footnotetext{
${ }^{55}$ M. Talik, op. cit., s. 69.

${ }^{56}$ Instrukcja proszowicka z 11 maja 1637 roku, [w:] ASWK, t. 2, cz. 1, s. 224.

${ }^{57}$ Ibidem, s. 225.

${ }^{58}$ Ibidem.

${ }^{59}$ R. Bosek, Stanowisko sejmiku proszowickiego $w$ sprawach skarbowych $w$ latach 1572-1648, AUW 1981, Historia, z. 34, s. 94.

${ }^{60}$ Instrukcja proszowicka z 11 maja 1637 roku, [w:] ASWK, t. 2, cz. 1, s. 226.

${ }^{61}$ Ibidem, s. 225.

${ }^{62}$ Sprawę tę proponowano odłożyć na kolejny sejm. Ibidem.
} 
z przekonania szlachty krakowskiej o rozwiązaniu problemu kozackiego, gdyż zanim odbyły się jeszcze sejmiki, na Zaporoże udali się komisarze (wojewoda podolski - Stanisław Potocki i podkomorzy czernihowski - Adam Kisiel) z zapłatą Kozakom zaległego żołdu za 3 lata do 1636 r. $^{63}$

Wiele wreszcie miejsca poświęcono w proszowickiej instrukcji sprawom, które nie zostały podniesione przez króla $\mathrm{w}$ legacji. Wśród nich na pierwsze miejsce wysuwa się kwestia, jakże istotna z perspektywy województwa krakowskiego, a mianowicie dotycząca ślubu Władysława IV z Cecylią Renatą. Decyzja o małżeństwie z córką cesarską, przedstawiona już na sejmie zwyczajnym 1637 roku i potwierdzona 16 marca tegoż roku paktem familijnym między Habsburgami a polskimi Wazami ${ }^{64}$, poruszyła sejmikujących 11 maja w Proszowicach w kontekście zaplanowanego miejsca zaślubin - Warszawy. Szlachta w instrukcji poselskiej apelowała, iż jeśli „do tego przyść miało, aby ten akt nie w mieście stołecznym [Krakowie - D. M.], alie nad zwyczaj gdzieindzi miał być odprawowany, koronacyja jednak według prawa i zwyczaju Królowy Jej Mości aby w mieście tym stołecznym odprawowana beła" ${ }^{65}$. Tak więc szlachta stała na straży poszanowania zwyczaju koronacji w Krakowie, która bez wątpienia podnosiła rangę tego miasta.

Kolejną kwestię, poruszoną przez sejmikujących, a przemilczaną w legacji królewskiej, stanowiły cła morskie. Rozejmem sztumsdorfskim z 12 września $1635 \mathrm{r}$. Władysław IV otrzymał prawo do pobierania tego podatku przez dwa lata w portach Gdańska, Kłajpedy, Libawy, Piławy i Windawy. Po roku jednak zrezygnował $\mathrm{z}$ tego przywileju w zamian za zaproponowaną przez gdańszczan kwotę 800 tys. zł. Sprawa, wydawałoby się rozwiązana i zamknięta, odrodziła się na nowo w $1637 \mathrm{r}$. Henryk Wisner twierdzi, iż problem tkwił we flocie wojennej, którą Władysław IV począł tworzyć w przededniu możliwej wojny ze Szwecją, a po zawarciu rozejmu próbował przekształcić w przynoszącą zyski flotę handlową ${ }^{66}$. Gdy jednak to przedsięwzięcie zakończyło się fiaskiem, monarcha zaczął poszukiwania sposobu zdobycia pieniędzy na utrzymanie statków. Dalej w swych rozważaniach posuwa się Władysław Czapliński, wskazując na bardzo trudną sytuację finansową Władysława IV ${ }^{67}$. Pieniądze otrzymane od Gdańska szybko się rozeszły, długi królewskie ciągle rosły, a na zbliżający się ślub należało szykować niemałe środki. Stąd potencjalne dochody z przywróconych ceł miały

${ }^{63}$ A. Filipczak-Kocur, Skarb, op. cit., s. 51; eadem, Skarbowość, op. cit., s. 188.

${ }^{64}$ J. Dzięgielewski, O tolerancję, op. cit., s. 108.

${ }^{65}$ Instrukcja proszowicka z 11 maja 1637 roku, [w:] ASWK, t. 2, cz. 1, s. 225.

${ }^{66} \mathrm{H}$. Wisner, O cet morskich fundacji dwa druki polemiczne z czasów Władysława IV, [w:] Ludzie, kontakty, kultura XVI-XVIII w. Prace ofiarowane Profesor Marii Boguckiej, J. Kawecki, J. Tazbir (red.), Warszawa 1997, s. 237-238.

${ }^{67}$ W. Czapliński, Polska a Prusy i Brandenburgia za Władysława IV, Wrocław 1947, s. 190. 
być przeznaczone według tego historyka na poratowanie wyczerpanej szkatuły królewskiej, a nie, jak sugerowali niektórzy ówcześnie żyjący - Jerzy Ossoliński, Adam Kazanowski, czy Gerard Denhoff - na wzmocnienie Rzeczypospolitej ${ }^{68}$. Stąd zapewne projekt ten nie znalazł się w legacji królewskiej.

Ponadto należy wskazać, iż cła morskie były podatkiem, który choć w sposób pośredni, ale dotykał przede wszystkim warstwę prawie całkowicie wolną od obciążeń, mianowicie szlachtę. Skąd więc się wzięła kwestia celna w instrukcji poselskiej, skoro nie uwzględnił jej monarcha w instrukcji królewskiej na sejmiki? Wszystko to za sprawą taktyki, którą przyjął dwór w tej sprawie. Polegała ona na tym, by wśród szlachty wywołać wrażenie, iż projekt nie wyszedł od władcy, a z kręgów szlacheckich ${ }^{69}$. Wśród szlachty krakowskiej można poszukiwać zgłaszających postulaty wśród Korycińskich - głównie w osobie chorążego krakowskiego Mikołaja Korycińskiego, który był bratem Andrzeja Korycińskiego (to on bowiem, jak zobaczymy, wniósł tę sprawę pod obrady sejmowe). Być może dlatego $\mathrm{w}$ instrukcji proszowickiej pozytywnie przedstawiono kwestię celną „iż cła morskie dotąd R. P. pożytku żadnego nie czynią, aby one in commodum et utilitatem R. P. akomodowane beły"70. Posłowie krakowscy mieli na sejmie wnosić, by przez trzy lata cłami zarządzał król, po czym zarząd i dochody miały przejść na Rzeczpospolitą ${ }^{71}$.

$\mathrm{Na}$ koniec należy wspomnieć, iż sejmikujący nakazali swym posłom, by ci na sejmie domagali się od króla, aby „raczeł gorącą instancyją uczynić u cesarza jm. [Ferdynanda III - D. M.] occasione rumpendorum pactorum zabiegając"72. Argumentem były krzywdy wynikające z łamania paktu ze strony Węgier i Śląska. Widać więc, iż szlachta krakowska nie dostosowała się do prośby królewskiej, by sprawy wewnętrzne odłożyć do przyszłego sejmu walnego, gdyż „natura sejmu teraźniejszego w tak ścisłym czasie uprzątnąć i ułacnić tego nie może”73.

W duchu tak spisanej instrukcji mieli wystąpić na zbliżającym się sejmie posłowie województwa krakowskiego. Tym razem sejmik proszowicki reprezentować mieli: Marcjan Chełmski, podkomorzy krakowski, Jerzy Sebastian Lubomirski, starosta dobczycki, Mikołaj Koryciński, chorąży krakowski, Jan Ścibor Chełmski, łowczy krakowski oraz Franciszek Dembiński i Stanisław Chrząstowski. Stanowili oni grono wytrawnych parlamentarzystów (z wyjątkiem Jana Ścibora Chełmskiego, który tym posłowaniem rozpoczynał dopiero karierę polityczną) o długim niekiedy stażu poselskim, już wypróbowanych

\footnotetext{
${ }^{68}$ Idem, Polska a Bałtyk w latach 1632-1648. Dzieje floty i polityki morskiej, Wrocław 1952, s. 106.

${ }^{69}$ Ibidem, s. 108.

${ }^{70}$ Instrukcja proszowicka z 11 maja 1637 roku, [w:] ASWK, t. 2, cz. 1, s. 225.

${ }^{71}$ Ibidem.

${ }^{72}$ Ibidem.

${ }^{73}$ Instrukcja królewska z kwietnia 1637 roku, [w:] APM, s. 4.
} 
w utarczkach sejmowych oraz cieszących się zaufaniem i uznaniem wśród szlacheckich wyborców. Posłowie ci byli niewątpliwie mocno związani z własnym województwem, choć i ich mógł pozyskać dla własnych celów władca, wykorzystując do tego prerogatywę rozdawnictwa godności państwowych. Nie wiadomo jednak, czy cała szóstka uczestniczyła w obradach. Na pewno na sejmie obecni byli: Marcjan Chełmski, Franciszek Dembiński i Mikołaj Koryciński.

Po uroczystej inauguracji sejmu 3 czerwca, izba poselska rozpoczęła prace 8 czerwca, by zakończyć je przygotowaniem projektów konstytucji, co miało miejsce 16 czerwca. Toczące się w tym czasie obrady, choć burzliwe i chaotyczne, objęły swym zakresem wszystkie niemal kwestie zaproponowane przez króla w legacji na sejmiki ( $\mathrm{z}$ wyjątkiem sprawy kozackiej - na sejmie wysłuchano tylko podziękowań posłów kozackich za wypłacenie żołdu za lata 1633 i 1634). Ponadto poddano pod dyskusję wiele spraw, które posłowie zaczerpnęli ze swych instrukcji lub - jak w przypadku ceł morskich - były one (tak uważa Władysław Czapliński) elementem gryparlamentarnej Władysława IV ${ }^{74}$. Posłowiekrakowscy byli podczas tych obrad bardzo aktywni, o czym świadczą liczne wzmianki na ich temat czynione przez autora diariusza ${ }^{75}$. Przy tym, jak można było zauważyć, wiernie działali z przekazaną im instrukcją, a co najważniejsze z perspektywy województwa dość skutecznie.

Już na samym początku sejmu stanęli w obronie kwestionowanej przez niektórych posłów prawomocności tego zgromadzenia. Podnosili, iż wszyscy obecni na poprzednim sejmie posłowie wyrazili jednomyślnie zgodę na zwołanie sejmu ekstraordynaryjnego i choć wówczas nie uchwalono żadnej konstytucji, to nie powinno się kwestionować rozporządzeń sejmu zwyczajnego. Ponadto podkreślali, że skoro większość sejmików wybrała posłów cum plena instructione, dokonano wyboru marszałka i wysłuchano wotów, to nie ma czasu na tę dyskusję, bo jest do rozwiązania wiele problemów związanych z zagrożeniem ze strony Turków i Moskwian ${ }^{76}$.

W kolejnej kwestii, która była przedmiotem dyskusji parlamentarnej, zapłaty zaległego żołdu, posłowie krakowscy zapowiedzieli, że nie podejmą dyskusji dopóki nie zostanie rozstrzygnięta kwestia, które województwa na sejmie 1635 r. nie zatwierdziły w pełni podatków, nie wydały ich bądź nie złożyły do skarbca. Przy tej okazji oskarżyli Litwinów, że w „retentis” znajdują się „4 Tonnen Goldes”,

${ }^{74}$ W. Czapliński, Polska a Bałtyk, op. cit., s. 108.

${ }^{75}$ Diariusz ten spisany przez agenta gdańskiego (Archiwum Państwowe w Gdańsku, 300,29/118) został częściowo opublikowany przez W. Czaplińskiego; zob. przyp. 14. W innych znanych mi relacjach z tego sejmu (A. S. Radziwiłł, Pamiętnik o dziejach w Polsce, t. 2, wyd. A. Przyboś i R. Żelewski, Warszawa 1980, s. 34-37 oraz fragment diariusza: Seym Dwuniedzielne Anni 1637, Archiwum Główne Akt Dawnych, Archiwum Zamoyskich, 3081) nie odnotowano działalności posłów sejmiku proszowickiego.

${ }^{76}$ Diariusz sejmu nadzwyczajnego 1637 roku, [w:] APM, s. 20. 
z czego pokaźną sumę mieli przekazać Władysławowi IV, co było - według nich - niezgodne $\mathrm{z}$ prawem. Wobec jednak zapewnień podskarbiego Tryzny, że w skarbie jest jeszcze wystarczająca ilość pieniędzy, postanowiono przeznaczyć ją na zapłatę wojsku. W ten sposób rozwiązano nabrzmiały konflikt, choć część posłów litewskich podnosiła, że pewne sumy powinny być zatrzymane na wypadek zagrożenia ze strony Moskwy. Spowodowało to ostrą reakcję Mikołaja Korycińskiego, który zarzucił Litwinom, że tak jak na poprzednim sejmie i teraz dążą oni do tego, by zgromadzenie rozeszło się bez uchwał77.

Ze strony posłów województwa krakowskiego wyszła ponadto inicjatywa, by zastanowić się nie tylko nad sprawą zapłaty wojsku, ale równocześnie omówić „de

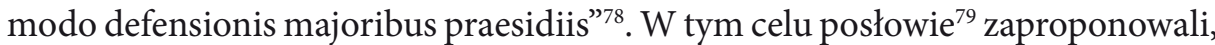
by spotkać się z hetmanem Koniecpolskim i wysłuchać jego uwag w tej materii. Niestety źródła nie donoszą, czy do wspólnych narad rzeczywiście doszło.

Również od Małopolan, a konkretnie od Andrzeja Korycińskiego ${ }^{80}$, popłynęła propozycja ponownego pobierania ceł morskich. W swojej mowie argumentował on, że Rzeczypospolitej przysługuje prawo do nakładania i pobierania ceł morskich w celu utrzymania floty. Przychylną postawę w tej kwestii przyjął również Franciszek Dembiński, który stwierdzeniem, że cło wraz z „classe maritima” będzie konieczne, rozzłościł starostę puckiego Jana Działyńskiego. Ponadto postulował obliczenie wpływów z tych ceł pod kątem opłacalności i zdać relację o nich całej Rzeczypospolitej na kolejnym sejmie ${ }^{81}$.

Zgodnie $\mathrm{z}$ powierzoną im instrukcją, krakowianie domagali się, by zastrzeżono konstytucją koronację królowej w Krakowie oraz wysunęli żądania powołania komisji w sprawie granic z Węgrami i Śląskiem. Ponadto godzili się na czopowe i jedno podymne, a na wypadek niewystarczających innych środków - na pospolite ruszenie ${ }^{82}$.

Uchwalone na sejmie konstytucje mogły satysfakcjonować szlachtę krakowską. Na pierwszym miejscu wśród nich znalazła się konstytucja o sejmach ekstraordynaryjnych, zakazująca królowi zwoływania tego typu zgromadzeń, na których nie można by omawiać grawaminów szlachty. Na przyszłość zezwolono królowi zwoływać jedynie sześcioniedzielne sejmy i te w razie nagłej potrzeby

${ }^{77}$ Ibidem, s. 22-23.

${ }^{78}$ Ibidem, s. 27.

${ }^{79}$ P. Paradowski podaje, że inicjatywa wyszła od podkomorzego krakowskiego Marcjana Chełmskiego, a poparli go posłowie małopolscy: krajczy koronny Mikołaj Ostroróg i marszałek Jabłonowski. Zob. idem, $W$ obliczu, op. cit., s. 153.

${ }^{80}$ Historycy zastanawiali się już, dlaczego z tą propozycją wystąpił właśnie Andrzej Koryciński. Zob. W. Czapliński, Polska a Bałtyk, op. cit., s. 108; H. Wisner, Władysław IV, Wrocław 1995, s. 122.

${ }^{81}$ Diariusz sejmu nadzwyczajnego 1637 roku, [w:] APM, s. 28; M. Sokalski, Kilka uwag o działalności sejmowej Franciszka Dembińskiego, SH 1999, z. 3, s. 354.

${ }^{82}$ Ibidem, s. 29-30. 
skracać ${ }^{83}$. W dalszej kolejności postanowiono o zapłacie wojsku. Ostatecznie zaakceptowano nowe zaciągi, a to „za pewną wiadomością (...), Hetmana naszego Koronnego", który to potwierdzał niebezpieczeństwo grożące Rzeczypospolitej ze strony pogan ${ }^{84}$. Na ten cel przeznaczono czopowe, którego „exakcya a die prima Iulij, w roku teraznieyszym poczynać się ma, a do takowego dnia w roku 1638 kończyć się będzie" ${ }^{35}$ oraz pogłówne żydowskie w kwocie 60 tys. zł polskich ${ }^{86}$. Ponadto uchwalono konstytucję w sprawie armaty i kwarty. Postanowiono, iż kwartę przeznacza się tylko i wyłącznie na armatę, a oddawanie jej ma odbywać się w Rawie, „a potym od Wielmożnego Podskarbiego (...), do rąk Starszego nad armatą, który ma być szlachcie dobrze osiadły, et iuratus, odsyłana była" ${ }^{87}$. Podjęto decyzję o powołaniu komisji do spraw granicznych z Węgrami i Śląskiem oraz uchwalono konstytucję o Trybunale Radomskim, przed którym mieli złożyć sprawozdanie także podskarbi i miasta pruskie. Z kolei sprawa powiatów Lęborka i Bytowa, która podzieliła sejmujących, stanęła na decyzji o przyłączeniu ich do Korony. Kwestię zaś ordynacji tych ziem przesunięto na przyszły sejm ${ }^{88}$. Sprawa dotycząca pospolitego ruszenia zakończyła się ostatecznie na tym, że poszczególne województwa zgodziły się wziąć ją „do braci”" ${ }^{99}$. Miały one jednak potraktować ten środek jako ostateczny, gdyby „gwałtowne pericula (...) nie mogły być odwrócone innymi sposobami" ${ }^{90}$. W końcu konstytucja dotycząca ceł morskich, o które w czasie sejmu trwała najzagorzalsza walka, powierzała królowi obmyślenie sposobu realizacji zamierzenia, ale i zastrzegała, że nie może naruszać wolności i przywilejów „tak stanu szlacheckiego jako i miast”. Widać więc, że tekst sformułowano dość niejasno, pozwalając władcy ,inire modos et rationes, jakoby takowe cła do swego mogły przyjść porządku”. Poza tym jednak stwierdzono, że niektóre województwa i powiaty Wielkiego Księstwa Litewskiego

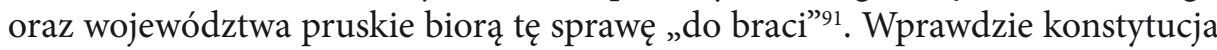
ujmowała sprawę jako jeszcze niezakończoną, ale chyba nikt w Rzeczypospolitej nie miał wątpliwości, że król zechce ją jak najszybciej wprowadzić w życie.

Podsumowując, należy stwierdzić, iż generalnie omawiany sejm stanowił sukces króla i jego zwolenników. Przede wszystkim, pomimo podejmowanych prób, żadnej z grup nacisku nie udało się zerwać obrad, szczególnie wykorzystując

\footnotetext{
${ }^{83}$ Ibidem, s. 33.

${ }^{84}$ Przyczynienie wojska, [w:] VL, t. 3, s. 433.

${ }^{85}$ Czopowe Koronne, [w:] VL, t. 3, s. 435-436.

${ }^{86}$ Pogłowne żydowskie w Koronie, [w:] VL, t. 3, s. 436.

${ }^{87}$ Quarta na armate naznaczona, [w:] VL, t. 3, s. 436.

${ }^{88}$ Reinkorporacya Powiatow, Lembuku y Bitowa, [w:] VL, t. 3, s. 436.

${ }^{89}$ Diariusz sejmu nadzwyczajnego 1637 roku, [w:] APM, s. 35.

${ }^{90}$ Pospolite ruszenie, [w:] VL, t. 3, s. 433.

${ }^{91}$ Cła morskie, [w:] VL, t. 3, s. 436.
} 
argument braku jego prawomocności. Król zobowiązany tylko został na przyszłość zwoływać zjazdy ekstraordynaryjne „za zgodą wszech Stanow, vim legis (...) za radą Panow Senatorow oboyga narodow"92. Ponadto, zgodnie z celem złożenia tego sejmu, uchwalono konstytucje niezbędne dla bezpieczeństwa Rzeczypospolitej. Choć opinia szlachecka negatywnie ustosunkowała się do kwestii samowolnego powiększenia wojska przez władcę i ostrzegała go przed takim postępowaniem na przyszłość ${ }^{93}$, to jednak zaakceptowała nowe zaciągi. Poza tym uchwalono podatki. Mimo, iż było to tylko jedno czopowe i pogłówne żydowskie, czyli w najlepszym przypadku około 800 tys. zl, a zaległy żołd w czerwcu osiągał sumę około $1 \mathrm{mln}$ zł, zadawalać musiały króla ${ }^{94}$. Była bowiem to i tak korzystniejsza sytuacja niż ta, w której znalazł się on w marcu 1637 roku. Nie pozostawiono tym razem Rzeczypospolitej bez obrony, choć kwestia realności zagrożenia zewnętrznego w owym czasie jest dyskusyjna. Można by więc wnioskować, iż propaganda królewska, zaangażowanie i determinacja dworu, przyniosły dlań zamierzony skutek. Tym bardziej jest to widoczne w przeforsowaniu na sejmie konstytucji o cłach morskich, choć kwestia ta nie znalazła się ani w legacji królewskiej, ani w propozycji od tronu. Dzięki pomocy senatorów i posłów, w tym i z województwa krakowskiego, Władysław IV zrealizował swój najważniejszy plan - zdobył dodatkowe źródło pieniędzy. W kunsztownie bowiem sformułowanej na sesji kanclerskiej konstytucji można się było dopatrzyć upełnomocnienia króla do wprowadzenia ceł.

Uchwały zapadłe na sejmie nadzwyczajnym $1637 \mathrm{r}$. odpowiadały postulatom szlachty zebranej w Proszowicach, wyrażonym w sejmikowej instrukcji. Warto choćby wspomnieć decyzję o utrzymaniu zaciągniętego suplementu, o cłach morskich, na których pobieranie województwo krakowskiewyraziło swą aprobatę, czy też postanowienie o przygotowaniu obrony przed niebezpieczeństwem tureckim. Ponadto, zgodnie z oczekiwaniami szlachty krakowskiej, a wbrew planom królewskim, uchwalono konstytucję o reinkorporacji powiatów lęborskiego i bytomskiego. Powołano do życia Trybunał Radomski, w którym województwo krakowskie miało mieć swojego przedstawiciela w osobie łowczego krakowskiego Jana Ścibora Chełmskiego ${ }^{95}$. Poza tym uzyskano na sejmie akceptację „authoritate conventus praesentis laudum sejmiku na wybieranie

${ }^{92}$ Wstęp do Konstytucji Sejmu Walnego Koronnego Warszawskiego Dwuniedzielnego, [w:] VL, t. 3, s. 433 .

${ }_{93}, Y$ lubo to u Nas extorsit necessitas, że takowe zaciągnienie stało się exstra consensum omnium ordinum; jako na tym sejmie nie mogliśmy derogować prawu, tak i napotym przy prawie zostawać będziemy”. Przyczynienie wojska, [w:] VL, t. 3, s. 433.

${ }^{94}$ Liczby podaję za: A. Filipczak-Kocur, Skarb, op. cit., s. 64.

${ }^{95}$ Trybunat Radomski, [w:] VL, t. 3, s. 433. 
czopowego uchwalone" ${ }^{\text {"96 }}$. Zobowiązany został do tego skarbnik krakowski Stefan Chełmski, który z naznaczonej województwu krakowskiemu kwoty 60 tys. zł „rachunek ma czynić tylko samemu Woiewodztwu, na pierwszym Seymiku po wybieraniu"97. Również kwestia niepodnoszona w legacji królewskiej, a bardzo istotna z perspektywy województwa krakowskiego, dotycząca „wielkich krzywd, które się dzieją ze strony Węgier i Śląska”, znalazła rozwiązanie na sejmie. W skład komisji powołanych na mocy konstytucji do rozwiązania tej sprawy weszli m.in.: Mikołaj Koryciński, Stanisław Lubomirski, Jan Zebrzydowski, Marcjan Chełmski, Franciszek Dembiński (komisarze od Królestwa Węgierskiego i ziemi siedmiogrodzkiej) oraz Jan Ścibor Chełmski, Achacy Przyłęcki, Samuel Czarnocki, Stanisław Dembiński (komisarze od Śląska, Margrabstwa i Pomorstwa $)^{98}$. Byli to ludzie związani z województwem, więc szlachta krakowska mogła się spodziewać pozytywnych rozstrzygnięć. Wśród wielu spraw była - jak sądzę - tylko jedna, która nie mogła szlachty krakowskiej satysfakcjonować. Dotyczyła ona miejsca koronacji przyszłej małżonki Władysława IV - Cecyli Renaty. Pomimo postulatów zgłoszonych w instrukcji poselskiej, by zgodnie ze zwyczajem ceremonia ta odbyła się w Krakowie i usilnych starań czynionych przez posłów krakowskich w tej mierze na sejmie, koronacja miała miejsce 13 września 1637 r. w Warszawie ${ }^{99}$.

Przykłady powyższe niosą ze sobą obraz raczej przychylnego odbioru efektów pracy sejmu przez województwo krakowskie. Ponadto świadczyć o tym może brak protestacji złożonych pod adresem uchwalonych konstytucji, które wcześniej niejednokrotnie napływały z Proszowic ${ }^{100}$. By stwierdzić, iż rzeczywiście tak było, należałoby sięgnąć do akt sejmiku relacyjnego. Niestety, nie odnalazłam żadnych źródeł na jego temat - ani instrukcji królewskiej ${ }^{101}$, ani laudum sejmiku. Można jedynie przypuszczać, iż odbył się on w lipcu bądź sierpniu 1637 r., ponieważ „do braci” poszczególne województwa wzięły sprawę

${ }^{96}$ Approbatio laudorum, [w:] VL, t. 3, s. 436.

${ }^{97}$ Czopowe Koronne, [w:] VL, t. 3, s. 436.

${ }^{98}$ Kommissya od Wegier y Śląska, [w:] VL, t. 3, s. 437.

${ }^{99}$ Przeprowadzenie koronacji w Warszawie, a nie w Krakowie było powodem, dla którego na najbliższym sejmie (w marcu 1638 r.) głównie szlachta krakowska doprowadziła do uchwalenia konstytucji przypominającej, gdzie zwyczajowo należy odprawiać koronację. Zob. Koronacya, [w:] VL, t. 3, s. 448.

${ }^{100}$ Zob. np. Protestacja posłów na sejm województwa krakowskiego przeciw konstytucjom sejmu koronacyjnego 1633 r.w Krakowie 5 kwietnia 1633 r., [w:] ASWK, t. 2, cz. 1, s. 163-164. Należy jednak wziąć po uwagę możliwość niezachowania się takich protestacji.

${ }^{101}$ Sejmiki relacyjne obradowały w Wielkim Księstwie Litewskim z mocy postanowień III Statutu Litewskiego, a w Koronie zbierały się na mocy uchwały sejmowej lub zwoływane były przez króla po sejmach nadzwyczajnych. Zob. W. Kriegseisen, Sejmiki Rzeczypospolitej szlacheckiej w XVII i XVIII wieku, Warszawa 1991, s. 36. 
pospolitego ruszenia. Ponadto wiemy, że tego typu zjazdy odbyły się m.in. w Środzie ${ }^{102}$, na Litwie ${ }^{103}$ i w Prusach ${ }^{104}$.

Posłowie na sejmikach relacyjnych dość powszechnie kwestionowali uchwały sejmu i zapowiadali swe wystąpienia przeciw uchwalonym na nim konstytucjom. Patrząc przez pryzmat instrukcji poselskiej i jej realizacji na sejmie przez wybranych posłów, trudno sobie wyobrazić, iż sejmik proszowicki miał podobny przebieg. Nie można oczywiście tego wykluczyć, gdyż sejmik relacyjny, jak sejmik przedsejmowy, był „żywym ciałem”, które można było urabiać. Stąd niełatwo jednoznacznie stwierdzić, jaki był wówczas stosunek sejmikujących wobec postanowień sejmu.

Analiza działalności posłów krakowskich w izbie poselskiej wykazała, iż powierzona im przez sejmik misja niemal całkowicie została wypełniona, a uchwalone konstytucje są tego świadectwem. Otwarte pozostaje tylko pytanie: Czy przyczyniło się do tego skuteczne działanie Władysława IV i jego otoczenia, czy też tym razem postulaty królewskie zbiegły się częściowo z postulatami szlachty krakowskiej?

${ }^{102}$ Zwołany został na 15 lipca 1637 roku. W. Czapliński, Władysław IV, op. cit., s. 240; Laudum sejmiku średzkiego z 15 lipca 1637 roku. Zob. P. Paradowski, W obliczu, op. cit., s. 179.

${ }^{103}$ Ibidem, s. 241.

${ }^{104}$ Zwołany został na 3 sierpnia 1637 roku. Instrukcja królewska na sejmik pruski z 28 czerwca 1637 roku, [w:] APM, s. 43. 